\title{
ЗАСТОСУВАННЯ МАТЕМАТИЧНОЇ МОДЕЛІ ДЛЯ АНАЛІЗУ ТЕПЛОВОЇ РОБОТИ БЕТОННОГО СОНЯЧНОГО КОЛЕКТОРА
}

\author{
І.Л. Решетняк, канд. техн. наук, доцент, М.П. Сухий, канд. техн. наук, професор
}

Український державний хіміко-технологічний університет,

49000, пр-т Гагаріна, 8, м. Дніпро, Дніпропетровська область, Україна.

\begin{abstract}
Бетонні сонячні колектори давно застосовуються в якості низькотемпературних водопідігрівачів, наприклад для підігріву води в басейнах. Їхніми основними перевагами є дешевизна, простота виконання та високі експлуатаційні якості. Одним 3 сучасних напрямків застосування бетонних сонячних колекторів є їх інтегрування в фасади та дахи будівель та споруд. Їх можна встановлювати на будівлях, що мають історичну цінність, не порушуючи їх зовнішній вигляд. Перевагою таких систем є естетичність та міџність, через те щуо вони не містять крихкого скляного покриття. В той же час абсорбери без скління, особливо в холодний сезон та нічний час, можуть мати значні втрати тепла за рахунок конвективного теплообміну з навколишнім повітрям, а також через довгохвильове випромінювання в атмосферу. Для аналізу впливу різних факторів на теплову роботу сонячної системи з бетонним колектором використовували математичну модель. Вона розраховує зміни прямого і розсіяного сонячного випромінювання на поверхню колектора протягом дня з урахуванням місия розташування $i$ орієнтачї̈ приймаючої поверхні, пори року $i$ доби. В моделі вирішується задача нестаціонарної теплопровідності в бетонній плиті з вбудованою системою труб з цииркулюючою рідиною та баком-акумулятором. Режим добового водоспоживання враховується шляхом зміни режиму роботи ичиркуляиійного насоса. Модель застосовувалась для аналізу роботи бетонних колекторів для умов Украӥни. Виконані порівняльні розрахунки теплової роботи заскленого та незаскленого бетонного колектора. Показано, що в умовах роботи бетонного колектора із замкнутим контуром на ефективність сонячної системи істотно впливає об'єм теплового бака-акумулятора і режси відбору води, так як після закінчення сонячного дня значна частина тепла, накопиченого бетонним абсорбером, може бути втрачена в навколишне середовище. Була розглянута можливість покращзення корисного використання тепла, щңо накопичується бетонним абсорбером, після закінчення сонячного дня за рахунок збільшення об'єму бака-акумулятора $і$ різних режимів його розгрузки.
\end{abstract}

Ключові слова: бетонний сонячний колектор, бак-акумулятор, математична модель, вбудований колектор.

\section{MATHEMATICAL MODEL USING FOR ANALYSIS OF THE HEAT OPERATION OF CONCRETE SOLAR COLLECTOR}

I. Reshetnyak, candidate of technical science, M. Sukhyy, candidate of technical science, professor

Ukrainian State University of Chemical Technology,

49005, 8, Gagarina Ave., Dnipro, Dnipropetrovsk region, Ukraine.

Concrete solar collectors have long been used as low-temperature water heaters, for example for water heating in swimming pools. Their main advantages are cheapness, simplicity of realization and high operational qualities. One of the modern directions of concrete solar collector development is their integration into facades of buildings and constructions. They can be integrated to historical buildings without compromising the building's appearance. The advantage of such systems is their aesthetics and structural strength, as they do not contain a brittle glass coating. At the same time, non-glazed absorbers, especially in the cold season and at night, can have significant heat loss due to convective heat exchange with the ambient air, as well as by long-wave radiation into the atmosphere. A mathematical model was used to analyze the influence of various factors upon the heat operation of a solar system with concrete collector. It calculates the changes of direct and diffused solar radiation on the collector surface during the day, taking into account the surface location and orientation, and time of year and day. The model solves the problem of nonstationary heat conductivity in a concrete absorber with a built-in pipes system with circulating liquid and storage tank. The daily water consumption mode is taken into account by changing the water flow rate to the circulation pump. The model was used to analyze the concrete collectors operating under Ukrainian conditions. The comparative calculations of heat operation of glazed and unglazed concrete collector were performed. It is shown that the efficiency of the solar system is significantly affected by the storage tank volume and the mode of water withdrawal, when concrete collector operating under closed-circuit conditions. This is due to the fact that after a sunny day much of the accumulated heat can be lost to the environment. The possibility of better use of stored heat accumulated by the concrete absorber after the end of a sunny day by increasing the storage tank volume and various modes of tank unloading was studied.

Keywords: concrete solar collector, storage tank, mathematical model, building integration. 


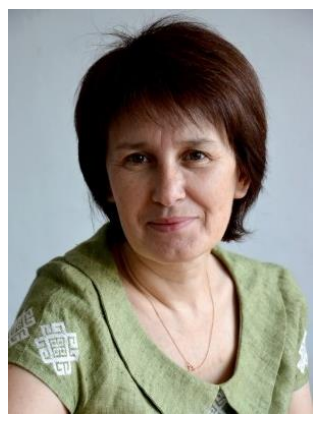

I.Л. Решетняк I. Reshetnyak

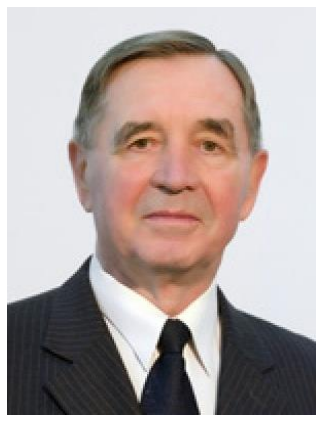

М.П. Сухий M. Sukhyy
Відомості про автора: доцент кафедри енергетики ДВНЗ «Український державний хіміко-технологічний університет», кандидат технічних наук.

Освіта: Вища. Московський інститут тонкої хімічної технології. Інженер-хімік-технолог. Наукова сфера: моделювання процесів. складного тепломасообміну, сонячна енергетика, дослідження процесів очищення питної води та водних розчинів.

Публікації: біля 40 наукових праць, 3 них 5 містяться в наукометричній базі Scopus та Web of Science.

ORCID: 0000-0001-6900-7428

Контакти: +380(097) 393-68-43

e-mail: iresh390@gmail.com

Відомості про автора: завідувач кафедри енергетики ДВНЗ «Український державний хіміко-технологічний університет», кандидат технічних наук, професор

Освіта: Вища. Дніпропетровський хімікотехнологічний інститут. Інженер-хіміктехнолог.

Наукова сфера: матеріали для адсорбційного поглинання, акумулювання та трансформації теплової енергії, утилізація низькопотенційних енергоресурсів.

Публікації: більше 60 наукових праць, 3 них 8 містяться в наукометричній базі Scopus та Web of Science.

ORCID: 0000-0002-3906-4592

Контакти: (0562)-47-33-49

e-mail: kafenergy@ukr.net
Author information: associate professor of the Energy Department of SHEI Ukrainian State University of Chemical Technology, candidate of technical science.

Education: Moscow Institute of Fine Chemical Technology. Chemical engineer.

Research area: heat and mass transfer process modeling, solar energy, the study of drinking water and aquaeous solution purification.

Publications: about 40 scientific works, 5 Scopus and Web of Science.

ORCID: 0000-0001-6900-7428

Contacts: +38 (097) 393-68-43

e-mail: iresh390@gmail.com

Author information: Professor of the Energy Department of SHEI Ukrainian State University of Chemical Technology, candidate of technical science.

Education: Dniepropetrovsk Institute of Chemical Technology. Chemical engineer.

Research area: materials for heat energy adsorbtion, accumulation and transformation, utilization of low-potential energy resources.

Publications: more than 60 scientific works, 8 Scopus and Web of Science.

ORCID: 0000-0002-3906-4592

Contacts: (0562)-47-33-49

e-mail: kafenergy@ukr.net

Перелік використаних позначень та скорочень:

$T$ - температура

$a$ - температуропровідність;

$t$ - час;

$\varepsilon$ - ступінь чорноти поверхні бетону;

$I$ - потік повного сонячного випромінювання;

$\sigma$ - постійна Стефана-Больцмана;

$U$ - коефіцієнт теплових втрат колектора;

$q$ - щільність теплового потоку;

$k$ - коефіцієнт теплопередачі;

$\delta$ - товщина стінки труби;

$\lambda$ - теплопровідність матеріалу;

$\alpha$-коефіцієнт конвективного теплообміну;

$u$ - швидкість вітру;

$I_{s}$ - потік прямого сонячного випромінювання;

Вступ. Бетонні сонячні колектори давно застосовуються в якості низькотемпературних водопідігрівачів, наприклад для нагрівання води в басейнах. Їхніми основними перевагами $є$ дешевизна, простота виконання та високі експлуатаційні якості. За останнє десятиліття в європейських країнах спостерігається стійке зростання інтересу до сонячних систем, безпосередньо інтегрованих в фасади або покрівлю будівель [7]. Вони в основному призначені для отримання гарячої води для домогосподарств, але також застосовуються в індивідуальних системах опалення. В сучасних активних системах сонячний колектор пов'язаний
$I_{d}$ - потік дифузного сонячного випромінювання;

$\theta$ - кут між нормаллю до поверхні абсорбера і напрямком на Сонце;

$\tau_{b}$ - коефіцієнта пропускання атмосфери;

$m$ - коефіцієнт атмосферної маси для умов ясного неба;

$\alpha_{z}$ - значення зенітного кута Сонця;

$g$ - фактор мутності атмосфери;

$\rho_{w}$ - щільність рідини;

$c_{w}$ - теплоємність рідини;

$u_{w}$ - швидкість рідини;

$m_{w}$ - витрати рідини;

$V_{b}-$ об'єм рідини в баку;

$A$ - площа поверхні абсорбера.

циркуляційним контуром 3 баком-акумулятором, в якому протягом дня накопичується тепло. Нагріта вода може безпосередньо відбиратися в основну систему підігріву, яка використовує електрику або органічне паливо, або передавати тепло в цю систему за допомогою теплообмінника. Одним 3 напрямків, які мають розвиток в останні роки, $\epsilon$ застосування вбудованих в будівлі масивних сонячних колекторів $[3,4,9]$. В масивних колекторах замість тонкого металевого абсорбера зазвичай використовується бетонна плита 3 вбудованою мережею труб для циркуляції води або соляного розчину. Попередньо відлиті бетонні абсорбери 
можуть бути фабрично виготовлені у вигляді будівельних панелей i застосовані в якості елементів фасаду або даху. Такі пристрої можуть мати або ні скляне покриття [3]. Перевагами незасклених систем $€$ їх естетичність і міцність. Також вони можуть встановлюватися на будівлях, що мають історичну цінність, не порушуючи їх зовнішній вигляд [2]. В той же час незасклені абсорбери, особливо в холодний сезон та в нічний час, можуть мати значні втрати тепла за рахунок конвективного теплообміну с навколишнім повітрям, a також шляхом довгохвильового випромінювання в атмосферу.

Для вивчення характеристик бетонних сонячних колекторів різного типу були виконані експериментальні і теоретичні дослідження. В роботі [8] були визначені основні характеристики ряду відлитих бетонних сонячних колекторів с мережею ПВХ труб с метою оцінки можливості ï інтегрування в будівлю. Для покращення теплопереносу було розглянуто застосування вбудованої в бетонний абсорбер металевої сітки і показано, що такі колектори можуть бути ефективно інтегровані в будівлю [13]. Теплові та економічні характеристики інтегрованого в дах незаскленого бетонного сонячного колектора вивчались в роботі [12]. Результати експериментальних i теоретичних досліджень застосування вбудованих в фасади багато багатоквартирних житлових будинків незасклених бетонних сонячних колекторів для умов Ірландії наведені в роботах $[10,11]$. Автори показали можливу ефективність таких колекторів для різних погодних умов.

Постановка задачі. Спрощена схема активної сонячної системи 3 бетонним колектором показана на рис. 1. Вона включає бетонний абсорбер 1, циркуляційний насос 2, бак-акумулятор 3, контролер 4 з датчиками 5 для виміру температур рідини. Для можливості наповнення та відбору води з баку призначена трубна лінія 6.

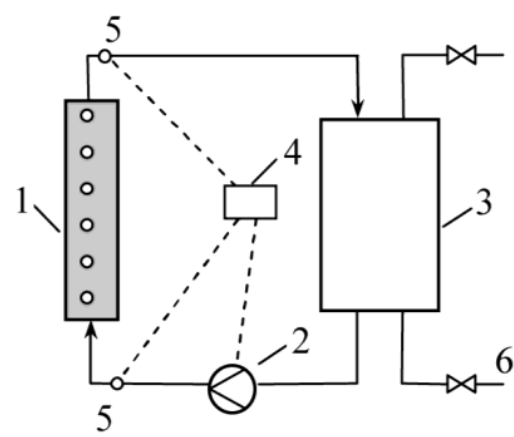

Рис. 1. Сонячна система с бетонним колектором.

Fig. 1. Solar system with concrete collector.
Абсорбер розглянутого сонячного колектора являє собою бетонну плиту, в якій на невеликій глибині від поверхні, що нагрівається, розташований трубний пучок, по якому циркулює рідина, що нагрівається. Труби розташовуються паралельно у вигляді змійовика 3 постійним кроком. Відкрита поверхня плити служить для поглинання тепла сонячного випромінювання, а решта поверхні плити теплоізольовані.

Протягом дня абсорбер накопичує тепло, отримане за рахунок сонячного випромінювання, і перерозподіляє його в бак за рахунок роботи циркуляційного насоса. Якщо різниця температур води на виході з колектора і в бакуакумуляторі стає менше $1^{\circ} \mathrm{C}$, то контролер зупиняє роботу циркуляційного насоса.

Об’єм бака-акумулятора тепла для гарячої води в домогосподарстві залежить від багатьох факторів. Виробники сонячних систем для плоских колекторів рекомендують мати об'єм бака-акумулятора $50-70$ л $\quad$ на $1 \mathrm{~m}^{2}$ площі абсорбера. Проте, для різних типів сонячних систем i умов їх застосування доцільно мати баки-акумулятори іншого об'єму [11].

Для оцінки впливу різних факторів на характеристики інтегрованих в будівлю бетонних сонячних колекторів застосовувалися різні математичні моделі, наприклад $[4,10,11,13]$. В то же час відкритим залишається питання про використання теплоти, накопленої абсорбером після закінчення сонячного дня. Це питання $\epsilon$ актуальним, тому що теплові ємності бетонного абсорбера i бака-акумулятора мають один порядок величин. В результаті робота системи суттєво залежить від режиму водоспоживання. Для врахування цих факторів застосовується модель, що враховує нестаціонарні процеси у бетонному адсорбері, мережі труб та бакуакумуляторі при різних режимах водоспоживання.

Математична модель. Переніс тепла в бетонній плиті абсорбера описується рівнянням теплопровідності:

$$
\frac{\partial T}{\partial t}=a\left(\frac{\partial^{2} T}{\partial x^{2}}+\frac{\partial^{2} T}{\partial y^{2}}+\frac{\partial^{2} T}{\partial z^{2}}\right) .
$$

В цьому рівнянні $T=T(x, y, z)-$ температура бетону, $a$ - температуропровідність бетону, $x$ i $y$ горизонтальна i вертикальна координати поперечного перерізу секції, $z$ - поздовжня координата секції, $t$ - час.

Щільність результуючого теплового потоку $q_{p}$ в довільній точці поверхні незаскленого 
колектора, що нагрівається, визначається рівнянням:

$$
q_{p}=\varepsilon\left[I+\sigma\left(T_{n}^{4}-T_{p}^{4}\right)\right]+\alpha\left(T_{a}-T_{p}\right) .
$$

Тут $\varepsilon-$ ступінь чорноти поверхні бетону, що нагрівається, I - потік повного сонячного випромінювання, $\sigma-$ постійна СтефанаБольцмана, $T_{n}$ - ефективна температура неба, $T_{p}$ - температура в обраній точці поверхні, що нагрівається, $T_{a}$ - температура навколишнього повітря, $\alpha$ - коефіцієнт конвективного теплообміну поверхні і навколишнього повітря.

Для заскленого колектора щільність результуючого теплового потоку розраховується як:

$$
q_{p}=I \varepsilon+U\left(T_{a}-T_{p}\right)
$$

де $U$ - коефіцієнт теплових втрат колектора.

На інших поверхнях секції приймається умова ідеальної ізоляції, тобто результуючий тепловий потік для цих поверхонь дорівнює 0.

На межі між бетоном і поверхнею труби, по якій циркулює рідина, тепловий потік $q_{t}$ визначається як

$$
q_{t}=k_{t}\left(T_{w}-T_{t}\right),
$$

де $T_{t}$ - температура бетону на межі з трубою, $T_{w}-$ температура води в трубі, $k_{t}-$ коефіцієнт теплопередачі, який визначається виразом:

$$
k_{t}=1 /\left(1 / \alpha_{w}+\delta / \lambda_{t}\right) .
$$

Тут $\delta-$ товщина стінки труби, $\lambda_{t}-$ теплопровідність матеріалу труби, $\alpha_{w}-$ коефіцієнт конвективного теплообміну між рідиною і трубою. Так як режим руху води в трубах ламінарний, то коефіцієнт тепловіддачі приймаємо для значень критерію $\mathrm{Nu}=4$.

Для визначення значень коефіцієнта конвективного теплообміну між навколишнім повітрям i поверхнею абсорбера для міських умов прийнята залежність [2]:

$$
\alpha_{V}=6,22+4,7 u^{0.785},
$$

де $u$ - швидкість вітру, м/с.

Потік сонячного випромінювання I, що падає на поверхню абсорбера, являє собою суму прямого випромінювання $I_{s}$ i дифузного (розсіяного) випромінювання $I_{d}$

$$
I=I_{s} \cos \theta+I_{d} .
$$

Тут $\theta$ - кут між нормаллю до поверхні абсорбера i напрямком на Сонце.

Для отримання протягом заданого дня року значень потоку $I$ в роботах $[2,10,11]$ автори використовували експериментальні дані для відповідного географічного розташування. Для умов України ми застосовували розрахунковий метод, основні положення якого наведені в $[1,14]$. Короткий виклад прийнятої розрахункової моделі для умов ясного неба наведено нижче.

Потік прямого сонячного випромінювання поблизу поверхні Землі дорівнює:

$$
I_{s}=I_{0} \tau_{b},
$$

де $I_{0}-$ сонячне випромінювання на зовнішній межі земної атмосфери, яке розраховується за формулою:

$$
I_{0}=1367 \cdot[1+0,033 \cos (2 \pi n / 365)],
$$

де $n$ - номер дня від початку року.

Для знаходження коефіцієнта пропускання атмосфери $\tau_{b}$ була обрана модель Мейнела [14]:

$$
\tau_{b}=0,7^{\mu}, \quad \mu=m^{0,678} .
$$

Тут коефіцієнт атмосферної маси $m$ для умов ясного неба розраховується залежно від значення зенітного кута сонця $\alpha_{z}$ :

$$
m=1 / \cos \left(\alpha_{z}\right),
$$

Потік дифузного випромінювання визначається за допомогою моделі [5]:

$$
I_{d}=120 g \cdot \exp \left[-1 /\left(0,4511+\sin \alpha_{z}\right)\right] .
$$

Тут $g$ - фактор мутності атмосфери, що розраховується як:

$$
g=0,796-0,01 \cdot \sin [0,986(n+284)] .
$$

Ефективна температура неба $T_{n}$, що входить до рівняння (2), знаходиться за допомогою простої моделі [14], що використовує тільки температуру навколишнього повітря

$$
T_{n}=0,0552 \cdot T_{a}^{1,5} .
$$

Для визначення температури рідини, що проходить через абсорбер, зазвичай застосовується допущення про квазістаціонарність процесу $[10,11,13]$. Це спрощує розрахунки, але може приводити до значних неточностей в разі перехідних процесів теплопереносу. Такі процеси мають місце в тих випадках, коли контролер установки змінюе або зупиняє роботу циркуляційного насоса. Для усунення такої проблеми ми використовували нестаціонарне рівняння енергії:

$$
\rho_{w} c_{w} \frac{\partial T_{w}}{\partial t}=-\rho_{w} c_{w} u_{w} \frac{\partial T_{w}}{\partial z}+k_{t} f\left(T_{s}-T_{w}\right),
$$

де $\rho_{w}$ i $c_{w}$ - щільність і теплоємність рідини, $u_{w}-$ швидкість рідини, $k_{t}-$ коефіцієнт теплопередачі, $f$ - питома поверхня труби.

Для визначення теплового стану бакаакумулятора використовувалась одновимірна 
модель. Теплові втрати бака і труб, що з'єднують його 3 абсорбером, прийняті рівними 0 . Температура $T_{b}$ рідини в баку визначається наступним рівнянням теплового балансу

$$
V_{b} \rho_{w} c_{w} \frac{d T_{b}}{d t}=m_{w} c_{w}\left(T_{w k}-T_{b}\right) .
$$

Тут $V_{b}-$ об'єм рідини в баку, $m_{w}$ - витрати рідини, $T_{w k}$ - температура рідини на виході 3 абсорбера.

Середня температура бетону $T_{c}$ та середня поточна ефективність колектора $\eta$ визначаються за формулами

$$
\begin{gathered}
T_{c}(t)=\frac{1}{V_{c}} \int_{V_{c}} T(x, y, z, t) d V_{c}, \\
\eta(t)=V_{b} \rho_{w} c_{w}\left[T_{b}(t)-T_{b}\left(t_{0}\right)\right] / A \int_{t_{0}}^{t} I(t) d t .
\end{gathered}
$$

Тут $V_{c}$ - об'єм бетону, $T_{b}(t)$ - температура води в баку в момент часу $t, t_{0}-$ момент часу початку роботи колектора, $I(t)$ - потік падаючого на поверхню абсорбера сонячного випромінювання, $A$ - площа поверхні абсорбера.

Рішення задачі чисельним методом. Перед моделюванням нестаціонарних процесів теплообміну в сонячному колекторі розраховуються значення повного потоку сонячного випромінювання $I$ протягом ясного дня 3 заданим інтервалом часу $t_{p}$. Для цього задаються параметри розташування сонячного колектора (широта і довгота місця розташування, азимутальний кут повороту від південного напрямку, кут нахилу поверхні до горизонту) и число днів від початку року. 3 тим же інтервалом часу $t_{p}$ за даними метеостанції задаються погодні умови (навколишня температура i швидкість вітру).

Для розрахунку теплопередачі в бетонному абсорбері розрахункова область розділяється по довжині на рівні сегменти, перенесення тепла між якими відбувається тільки за рахунок руху рідини в трубі змійовика. Для вирішення нестаціонарної задачі теплопровідності в кожному такому сегменті в роботах $[2,8]$ застосовувався метод кінцевих різниць, а в роботі [10] - метод кінцевих елементів з використанням пакета програм COMSOL Multiphysics. Ми використовували метод кінцевого об'єму, що забезпечило достатню точність рішення в умовах складної геометрії розрахункової області без застосування комерційних пакетів програм.

Температура бака $T_{b}$ на кожному розрахунковому кроці по часу знаходиться 3 рівняння теплового балансу (16), яке вирішується методом кінцевих різниць.
Результати розрахунків. За допомогою чисельної моделі вивчався нестаціонарний процес теплообміну у вбудованому в дах бетонному сонячному колекторі протягом доби в умовах весняного місяця (квітень) міста Дніпро (Україна). Абсорбер мав південний напрямок i кут нахилу до горизонту $30^{\circ}$. Геометричні розміри поверхні, що нагрівалась, були прийняті постійними $1 \times 1 \mathrm{~m}^{2}$. Товщина бетонної плити абсорбера змінювалась від 0,05 м до 0,15 м. Фізичні властивості бетону мали значення: щільність 2000 кг/ $\mathrm{m}^{3}, \quad$ теплоємність 1000 Дж/(кг·К), теплопровідність 2,5 Вт(м·К). Ступінь чорноти теплосприймаючої поверхні становила 0,9. Для трубного змійовика були прийняті значення параметрів: діаметр труби $0,02 \mathrm{M}$, товщина стінки 0,003 м, матеріал труб поліпропілен, крок труб 0,1 м, глибина труб від поверхні 0,02 м, витрати води $0,01 \mathrm{\kappa г} / \mathrm{c}$. Початкова температура води в баку і трубах, a також початкова температура бетонного абсорбера дорівнювали $7^{\circ} \mathrm{C}$. Розглядався ряд значень об'єму бака-акумулятора: 50, 100 і 150 л. Були прийняті наступні географічні координати місця розташування в Україні: широта $48^{\circ}$, довгота $35^{\circ}$. Погодинні значення температури повітря i швидкості вітру для цього місця розташування брались за даними метеостанції. На рис. 2 показана зміна потоку сонячного випромінювання на поверхню абсорбера i температури повітря протягом 24 годин, починаючи з 6-00.

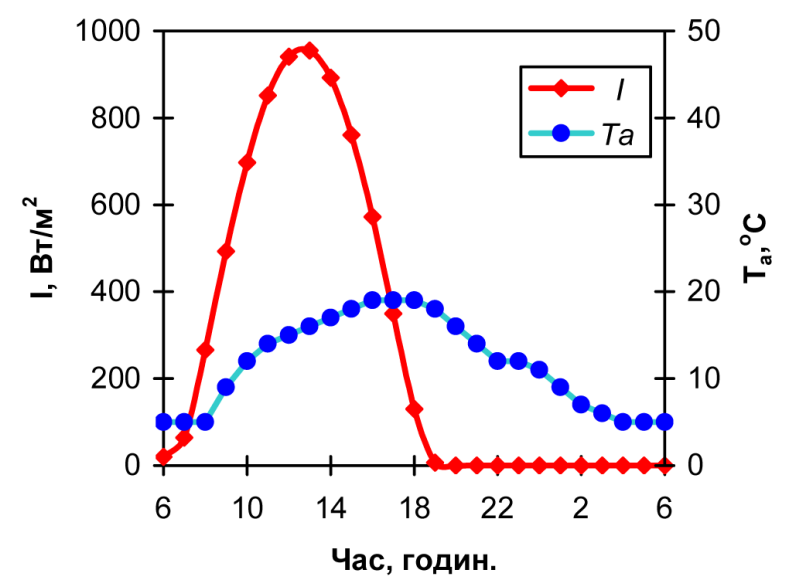

Рис. 2. Зміна потоку сонячного випромінювання $I$ i температури повітря $T_{a}$ протягом 24 годин.

Fig. 2. The change of total irradiance $I$ and ambient air temperature $T_{a}$ during 24 hours.

Спочатку розглядалася робота системи без відбору накопиченого тепла 3 бака-акумулятора. На рис. 3 показано зміну температури води в баку $T_{b}$ i середньої температури бетонного 
абсорбера $T_{c}$ для баків 3 різними об'ємами $V_{b}$. Після завершення сонячного дня ( 6 годин вечора) температура води на виході 3 колектора перестала перевищувати температуру бака i контролер зупинив роботу циркуляційного насоса. Далі бетонний абсорбер поступово втрачав накопичене тепло в навколишне середовище i до 2 годин ночі практично повернувся в початковий тепловий стан. Таким чином, якщо не відбувається відбір підігрітої води у вечірній час (пік споживання), для розглянутих погодних умов тепло абсорбера буде неможливо використовувати в ранковий пік споживання.

3 метою оцінки впливу скління бетонного колектора на його теплову роботу були виконані аналогічні розрахунки. При цьому результуючий тепловий потік на поверхню колектора розраховувався за формулою (3). Коефіцієнт втрат бетонного колектора $U$ змінюється в інтервалі приблизно від 2 до $8 \mathrm{BT} / \mathrm{M}^{2} \cdot К$. Для розрахунків було прийняте значення $U=$ $5 \mathrm{BT} / \mathrm{M}^{2} \cdot \mathrm{K}$. На рис. 4 показано зміну температур води в баку і середніх температур бетону для заскленого і незаскленого колекторів. Об'єм бака при цьому дорівнює 50 л. Як видно 3 рисунка, скління колектора призводить до істотного збільшення температури нагріву води в баку (від 30 до $\left.45^{\circ} \mathrm{C}\right)$. При цьому охолодження бетону в колекторі зі склінням істотно сповільнюється.

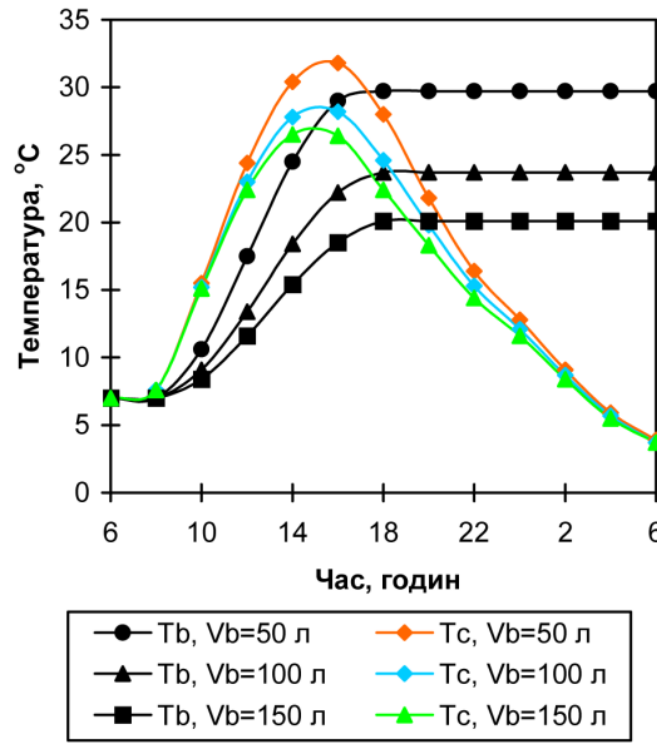

Рис. 3. Зміна температури води в баку $\boldsymbol{T}_{b}$ i середньої температури бетону $T_{c}$ для баків з різними об'смами $V_{b}$.

Fig. 3. The change of water temperature in the storage tank $T_{b}$ and average concrete temperature $\bar{T}_{c}$ for various tank volume $V_{b}$.
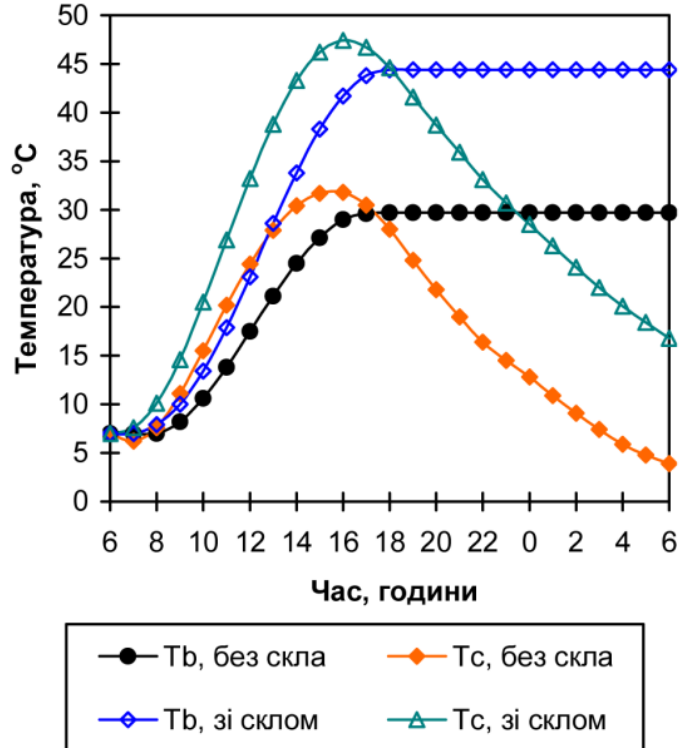

Рис. 4. Зміна температури води в баку $\boldsymbol{T}_{b}$ i середньої

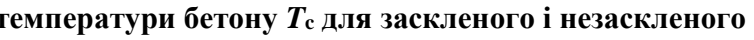
колекторів.

Fig. 4. The change of water temperature in the storage tank and average concrete temperature in the case of glazed and unglazed collector.

Далі вивчався вплив відбору води з бакаакумулятора на корисне використання тепла, накопиченого бетонним абсорбером. Хоча споживання гарячої води в домогосподарствах $\epsilon$ стохастичним процесом і залежить від багатьох факторів, для отримання наближених оцінок при моделюванні був обраний режим 3 постійною швидкістю відбору води 3 баку. Після завершення відбору бак заповнюється водою 3 початковою температурою $T_{f 0}$ i включається циркуляційний насос. На рис. 5 показано зміну температури води $T_{b}$ для випадку іiі відбору 3 баку починаючи 36 годин вечора 3 середньою витратою 10 л/хв. Зміну ефективності колектора для такого ж режиму наведено на рис. 6. Для всіх значень об'ємів бака $V_{b}$ ефективність зросла приблизно на 8\%. За рахунок збільшення об'єму бака від 50 до 150 л і зміни середньої швидкості відбору води з бака від 0 до 10 л/хв ефективність колектора збільшилася від 17,4\% до $37,7 \%$. У той же час, збільшення об'єму бака від 50 до 150 л привело до зниження температури води в баку в кінці сонячного дня від $30^{\circ} \mathrm{C}$ до $20^{\circ} \mathrm{C}$, а після відбору води з бака і заповнення його холодною водою за рахунок використання тепла абсорбера, температура бака зростає від $5^{\circ} \mathrm{C}$ до $12^{\circ} \mathrm{C}\left(V_{b}=\right.$ 50 л) і від $5^{\circ} \mathrm{C}$ до $9^{\circ} \mathrm{C}\left(V_{b}=150\right.$ л). 


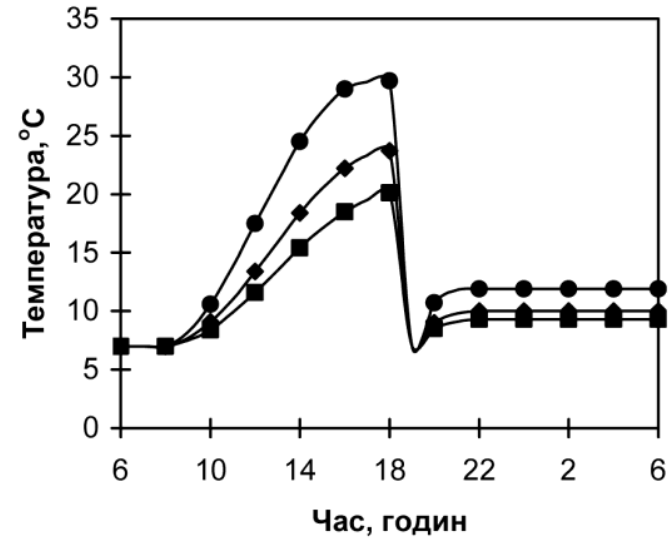

$\multimap \mathrm{Vb}=50$ л $-\mathrm{Vb}=100 л \multimap-\mathrm{Vb}=150 л$

Рис. 5. Добова зміна температури води в баку $T_{b}$ для різних значень об'сму бака $V_{b}$. Відбір з бака в 18-00 с витратою 10 л/хв.

Fig. 5. The changes of daily tank water temperature $\boldsymbol{T}_{\boldsymbol{b}}$ for different tank volumes $V_{b}$. The tank unloading with flow rate $10 \mathrm{l} / \mathrm{min}$ was at $18-00$.

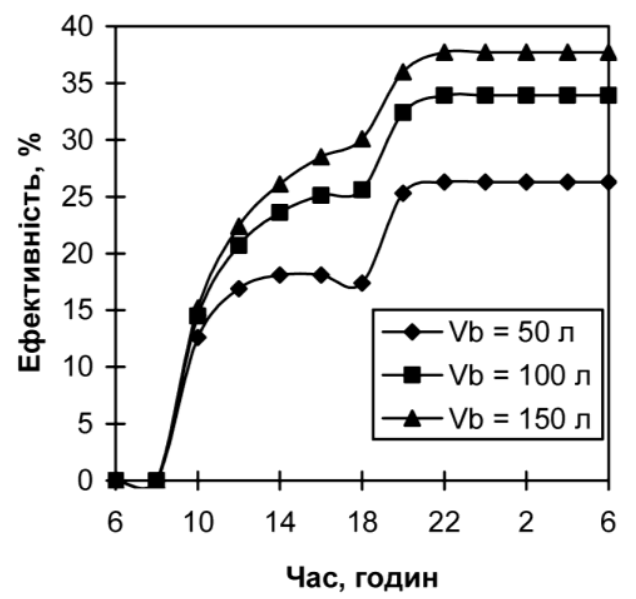

Рис. 6. Зміна середньої ефективності колектора для баків 3 різним об'смом $V_{b}$. Відбір з бака о 6 годині вечора 3 витратою 10 л/хв.

Fig. 6. The change of average collector efficiency for different tank volumes $V_{b}$. The tank unloading with flow rate $10 \mathrm{l} / \mathrm{min}$ was at 18-00.

Висновки. Шляхом застосування чисельної моделі були визначені характеристики вбудованого в дах незаскленого бетонного сонячного колектора в умовах весняного місяця в Україні.

Показано, що в умовах роботи бетонного колектора із замкнутим контуром на ефективність сонячної системи істотно впливає об'єм теплового бака-акумулятора i режим відбору води, так як після закінчення сонячного дня значна частина тепла, накопиченого бетонним абсорбером, може бути втрачена в навколишнє середовище. Математична модель може бути застосована для подальших досліджень масивних сонячних колекторів різного призначення та різних режимів водоспоживання. Вона може бути основою для використання при дослідженні ефективності систем «теплий будинок» з вбудованою мережею труб для циркуляції теплоносія.

1. Даффи Дж. А., Бекман У.А. Тепловые процессы с использованием солнечной энергии. Москва. Мир. 1977. $413 \mathrm{c}$.

2. Blecich P., Orlic I. Solar concrete collectors for heating of domestic hot water. Strojarstvo. 2012. Vol. 54(6). Pp. 423-432.

3. D'Antoni M., Saro O. Massive Solar-Thermal Collectors. A critical literature review. Renewable and Sustainable Energy Reviews. 2012. Vol. 16. Issue 6. Pp. 3666-3679.

4. D'Antoni M., Saro $O$. Energy potential of a Massive Solar-Thermal Collector design in European climates. Solar Energy. 2013. Vol. 93. Pp. 195-208.

5. El Mghouchi Y., El Bouardi A., Choulli Z., Ajzoul T. New model to estimate and evaluate the solar radiation. Int. Journal of Sustainable Built Environment. 2014. Vol. 3. Issue 2. Pp. 225-234.

6. Li T., Liu Y., Wang D., Shang K., Liu J. Optimization analysis on storage tank volume in solar heating system. Procedia Engineering. 2015. Vol. 121. Pp. 1356-1364.

7. Maurer C., Cappel C., Kuhn T.E. Progress in building-integrated solar thermal systems. Solar Energy. 2017. Vol. 154. Pp. 158-186.

8. Nayak J.K., Limaye R.G., Sukhatme S.P., Bopshetty S.V. Performance studies on solar concrete collectors. Solar Energy. 1989. Vol. 42. Issue 1. Pp. 45-56.

9. O'Hegarty R., Kinnane O., McCormack S.J. Review and Analysis of Solar Thermal Facades. Solar Energy. 2016. Vol. 135. Pp. 408-422.

10. O'Hegarty R., Kinnane O., McCormack S.J. Concrete solar collectors for façade integration: An experimental and numerical investigation. Applied Energy. 2017. Vol. 206 (15). Pp. 1040-1061.

11. O'Hegarty R., Kinnane O., McCormack S.J. Parametric investigation of concrete solar collectors for facade integration. Solar Energy. 2017. Vol. 153. Pp. 396-413.

12. Sarachitti R., Chotetanorm C., Lertsatitthanakorn C., Rungsiyopas $M$. Thermal performance analysis and economic evaluation of roof-integrated solar concrete collector. Energy and Buildings. 2011. Vol. 43. Issue 6. Pp. 1403-1408.

13. Sokolov M., Reshef M. Performance simulation of solar collectors made of concrete with embedded conduit lattice. Solar Energy. 1992. Vol. 48. Issue 6. Pp. 403-411.

14. Stein J.S., Hansen C.W., Reno M.J. Global Horizontal Irradiance Clear Sky Models: Implementation and Analysis. United States. N. p. 2012. 67 p. Web. https://doi.org/10.2172/1039404.

\section{REFERENCES}

1. Duffie J.A., Beckman W.A. Teplovie protsessi s ispolzovaniem solnechnoi energii. [Solar Engineering of Thermal Process]. Moskva. Mir. 1977. 413 p. [in Russian].

2. Blecich P., Orlic I. Solar concrete collectors for heating of domestic hot water. Strojarstvo. 2012. Vol. 54(6). Pp. 423-432.

3. D’Antoni M., Saro O. Massive Solar-Thermal Collectors. A critical literature review. Renewable and 
Sustainable Energy Reviews. 2012. Vol. 16. Issue 6 . Pp. 3666-3679.

4. D'Antoni M., Saro $O$. Energy potential of a Massive Solar-Thermal Collector design in European climates. Solar Energy. 2013. Vol. 93. Pp. 195-208.

5. El Mghouchi Y., El Bouardi A., Choulli Z., Ajzoul T. New model to estimate and evaluate the solar radiation. Int Journal of Sustainable Built Environment. 2014. Vol. 3. Issue 2. Pp. 225-234.

6. Li T., Liu Y., Wang D., Shang K., Liu J. Optimization analysis on storage tank volume in solar heating system. Procedia Engineering. 2015. Vol. 121. Pp. 1356-1364.

7. Maurer C., Cappel C., Kuhn T.E. Progress in building-integrated solar thermal systems. Solar Energy. 2017. Vol. 154. Pp. 158-186

8. Nayak J.K., Limaye R.G., Sukhatme S.P., Bopshetty S.V. Performance studies on solar concrete collectors. Solar Energy. 1989. Vol. 42. Issue 1. Pp. 45-56.

9. O'Hegarty R., Kinnane O., McCormack S.J. Review and Analysis of Solar Thermal Facades. Solar Energy. 2016. Vol. 135. Pp. 408-422.
10. O'Hegarty R., Kinnane O., McCormack S.J. Concrete solar collectors for façade integration: An experimental and numerical investigation. Applied Energy. 2017. Vol. 206 (15). Pp. 1040-1061.

11. O'Hegarty R., Kinnane O., McCormack S.J. Parametric investigation of concrete solar collectors for facade integration. Solar Energy. 2017. Vol. 153. Pp. 396-413.

12. Sarachitti R., Chotetanorm C., Lertsatitthanakorn C., Rungsiyopas $M$. Thermal performance analysis and economic evaluation of roof-integrated solar concrete collector. Energy and Buildings. 2011. Vol. 43. Issue 6. Pp. 1403-1408.

13. Sokolov M., Reshef M. Performance simulation of solar collectors made of concrete with embedded conduit lattice. Solar Energy. 1992. Vol. 48. Issue 6. Pp. 403-411.

14. Stein J.S., Hansen C.W., Reno M.J. Global Horizontal Irradiance Clear Sky Models: Implementation and Analysis. United States. N. p. 2012. 67 p. Web. https://doi.org/10.2172/1039404. [in English].

Стаття надійшла до редакції 07.07.20 Остаточна версія 17.12.20

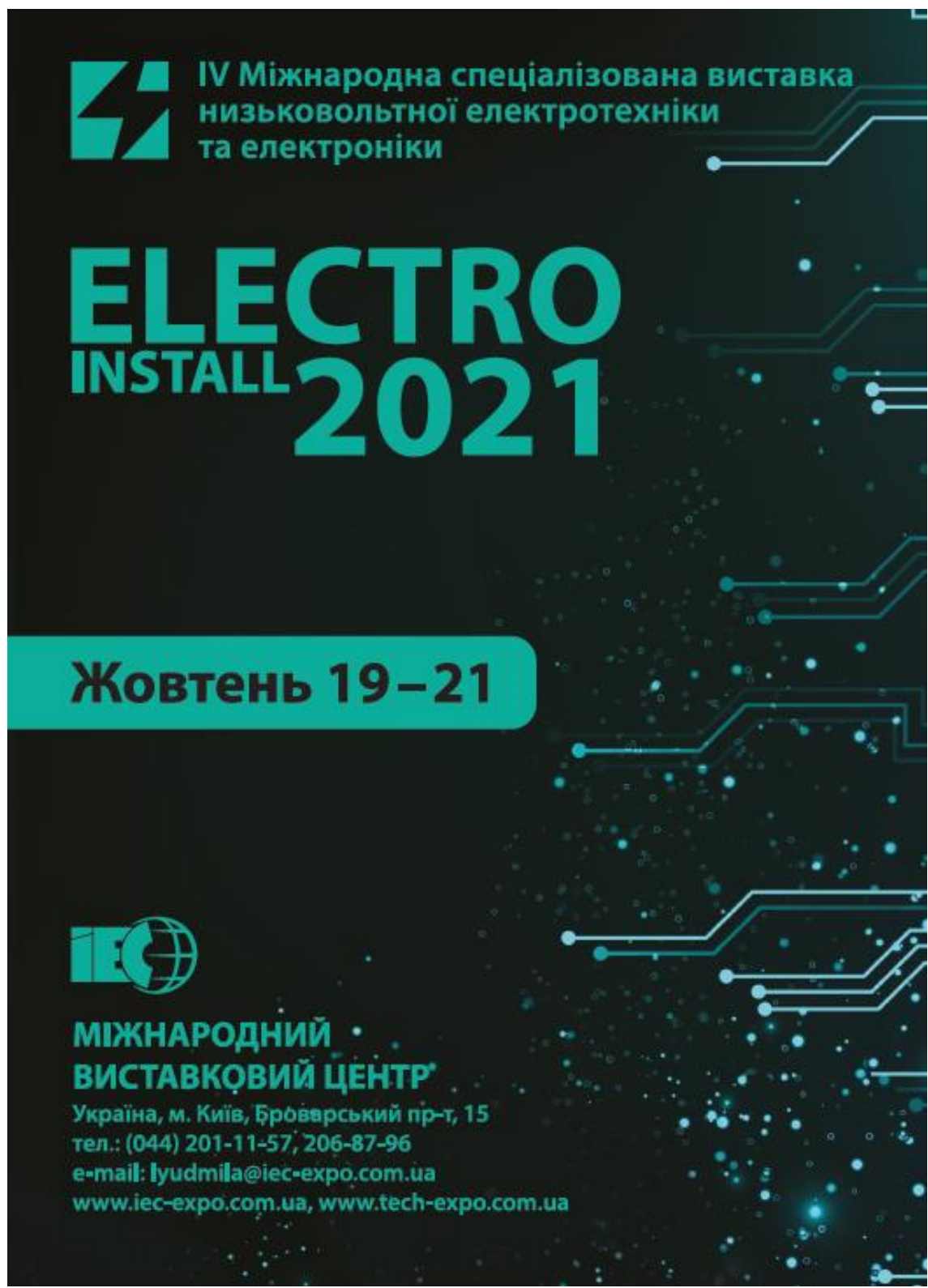

